\title{
ГЕНЕЗИС І РОЗВИТОК ІНСТИТУТУ АРЕШТУ МАЙНА У КРИМІНАЛЬНОМУ ПРОЦЕСІ
}

Баженова А. I.

Статтю присвячено дослідженню генезису $і$ розвитку інституту арешту майна у кримінальному прочесі. Зазначається, що бурхливе оновлення українського законодавства щодо протидії злочинності пов'язане з його приведенням до загальновизнаних міжнародних вимог та спрямоване на забезпечення прав учасників кримінального провадження, у тому числі осіб, які потерпіли від кримінального правопорушення. Одним із динамічних напрямів розвитку кримінального процесуального законодавства є інституm накладення арешту на майно, який постійно змінюється та доповнюється. Однак указаний інститут нині потребує деякого коригування з урахуванням окремих елементів, які пройшли становлення у законодавстві минулих часів та в певній частині можуть бути впроваджені у сучасне законодавство. Водночас подальший розвиток кримінального процесуального законодавства неможливий без знання історії виникнення певної юридичної проблематики для врахування окремих недоліків та позитивних елементів.

Зроблено висновки про те, що подальший розвиток кримінального процесуального законодавства, у тому числі інституту арешту майна у кримінальному процесі, неможливий без знання історії виникнення певної юридичної проблематики для врахування недоліків та окремих позитивних елементів. Сучасний стан інституту арешту майна у кримінальному процесі склався в процесі формування в різні етапи становлення Української держави від часів Київської Русі до набуття незалежності України. Прийняття нового КПК у 2012 р. за часів незалежності України стало відправною точкою у реформуванні кримінального процесуального законодавства України. Історію формування інституту арешту майна у кримінальному процесі на території України умовно поділено на п'ять історичних етапів: 1) до судової реформи 1864 р. в Російській імперії; 2) від судової реформи 1864 р. Әо Жовтневого перевороту 1917 р.; 3) від Жовтневого перевороту 1917 р. до прийняття у 1958 р. Основ кримінального судочинства Союзу РCP та союзних республік; 4) від прийняття у 1958 р. Основ кримінального судочинства Союзу РСР та союзних республік та на період дії КПК України 1960 р.; 5) від набрання чинності КПК України 2012 р. дотепер.

Ключові слова: інститут арешту майна у кримінальному процесі, Руська правда, Литовський статут, кримінальний процесуальний кодекс.

() Баженова А. І., 2020
Bazhenova A. I. Genesis and development of the institute of arrest of property in the criminal procedure

The article is devoted to the study of the genesis and development of the institution of seizure of property in criminal proceedings.

It is noted that the rapid update of Ukrainian legislation on combating crime is associated with its reduction to generally accepted international requirements and is aimed at ensuring the rights of participants in criminal proceedings, including persons who have suffered from a criminal offense. One of the dynamic directions of development of criminal procedural legislation is the institution of seizure of property, which is constantly changing and supplemented. However, this institution now needs some adjustment to take into account certain elements that have been formed in the legislation of the past and to some extent can be implemented in modern legislation. At the same time, further development of criminal procedural legislation is impossible without knowledge of the history of certain legal issues to take into account certain shortcomings and positive elements.

It is concluded that further development of criminal procedural legislation, including the institution of seizure of property in criminal proceedings is impossible without knowledge of the history of certain legal issues to take into account the shortcomings and some positive elements. The current state of the institution of seizure of property in the criminal process has developed in the process of formation in different stages of formation of the Ukrainian state from the times of Kievan Rus to the independence of Ukraine. The adoption of the new CPC in 2012 during Ukraine's independence was the starting point for reforming Ukraine's criminal procedure legislation. The history of the formation of the institution of seizure of property in criminal proceedings, on the territory of Ukraine, which is conditionally divided into five historical stages: 1) before the judicial reform of 1864 in the Russian Empire; 2) from the judicial reform of 1864 to the October coup of 1917; 3) from the October Revolution of 1917 to the adoption in 1958 of the Fundamentals of Criminal Procedure of the USSR and the Union Republics; 4) from the adoption in 1958 of the Fundamentals of Criminal Procedure of the USSR and the Union Republics and for the period of validity of the CPC of Ukraine in 1960; 
5) from the entry into force of the CPC of Ukraine in 2012 to the present.

Key words: institute of Seizure of Property in Criminal Proceedings, Ruska Pravda, Lithuanian Statute, Criminal Procedure Code.

Постановка проблеми та іï актуальність. Бурхливе оновлення українського законодавства щодо протидії злочинності пов'язане з його приведенням до загальновизнаних міжнародних вимог та спрямоване на забезпечення прав учасників кримінального провадження, у тому числі осіб, які потерпіли від кримінального правопорушення. Одним із динамічних напрямів розвитку кримінального процесуального законодавства $\epsilon$ інститут накладення арешту на майно, який постійно змінюється та доповнюється. Однак указаний інститут нині потребує деякого коригування з урахуванням окремих елементів, які пройшли становлення у законодавстві минулих часів та в певній частині можуть бути впроваджені у сучасне законодавство. Водночас подальший розвиток кримінального процесуального законодавства неможливий без знання історії виникнення певної юридичної проблематики для врахування окремих недоліків та позитивних елементів.

Аналіз останніх досліджень і публікацій. Питанням дослідження генезису і розвитку кримінального процесу, окремих елементів інституту арешту майна у кримінальному процесі присвятили свою увагу такі теоретики та практики, як: М.П. Водько, В.В. Горошко, П.Т. Землянський, В.Б. Іскандіров, Г.К. Кожевніков, С.М. Смоков, В.Я. Тацій та багато інших.

Метою статті $\epsilon$ дослідження генезису і розвитку інституту арешту майна у кримінальному процесі, запровадження періодизації вказаного інституту.

Виклад основного матеріалу. Перед тим як розглянути генезис і розвиток інституту арешту майна у кримінальному процесі, необхідно погодитися з відомим твердженням історичної концепції права про те, що «без історії юриспруденція сліпа» [1].

Як і всі інші інститути права, інститут арешту майна у кримінальному процесі пройшов становлення та розвиток протягом тривалого часу та має Свою історію. У міру формування норм права, які охороняли майнові права членів суспільства, з'являлися норми, спрямовані на здійснення відшкодування завданої шкоди. Але це був тривалий процес і в перших збірниках права норми, які у прямий постановці регулювали ці питання, відсутні.
Так, під час ознайомлення з пам'яткою юридичної думки України-Русі епохи Середньовіччя «Руською правдою» [2] не встановлено положень, які були прообразом заходів забезпечення кримінального провадження у вигляді позбавлення особи права на відчуження, розпорядження, користування майном, якщо воно $є$ доказом злочину або 3 метою подальшого забезпечення компенсації завданої майнової шкоди. Але вже в наявності конфіскація як міра кримінального покарання. Так, вищою мірою покарання в «Руській правді» були поток і пограбування, коли щодо майна правопорушника здійснювалася конфіскація, а його разом із сім'єю виганяли за межі общини або обертали на рабів. Такий вид покарання застосовувався до тих, хто вчинив підпал, розбій та конокрадство (ст. ст. 7, 35, 45, 83 розш. ред.) [3, с. 77].

У XIV-XVI ст. українські землі входили до складу Великого князівства Литовського, яке сучасники називали Литовсько-Руською державою. Ця обставина суттєво вплинула на розвиток правової культури українського, литовського, білоруського і російського народів. За шістдесят років литовський уряд тричі здійснював кодифікацію права, що було винятковим явищем для часів, коли прийняті закони залишалися чинними протягом століть. Статути 1529, 1566 і 1588 рр. вміщують цінний матеріал щодо характеристики соціальних, економічних і політичних відносин, суспільного і державного ладу, судової системи, галузевих норм права, які склалися на той час у Великому князівстві Литовському, у тому числі й на українських землях [4].

Більшість дослідників сходиться на думці, що майже весь період із XIV і до XVI ст., коли руські (білоруські та українські) землі влилися до Литовської держави i становили близько 90 відсотків території останньої, тут панувало звичайне руське право, норми якого застосовувалися не лише в етнографічних білоруських та українських областях, а й у самій Литві [3, c. 147].

У Статуті Великого князівства Литовського 1529 р. достатньо докладно розписано злочини та санкції за їх учинення, у тому числі матеріальні санкції, також указані окремі процесуальні моменти доказування вини, однак у Статуті також не визначено прообразу заходів забезпечення кримінального провадження шляхом позбавлення особи права на відчуження, розпорядження, користування майном, якщо воно $є$ доказом злочину або з метою подальшого забезпечення компенсації завданої майнової шкоди [5]. 
Водночас у вказаному Статуті прописано певні заходи процесуального забезпечення того часу. Так, указано, що якщо б хто-небудь не допустив шукати викрадені речі чи відбив полічне, а це було би доказано сторонніми людьми, з якими потерпілий прийшов зробити обшук у домі підозрюваного, то винний, будь то шляхтич чи проста людина, повинен платити стільки, скільки вкаже потерпілий під присягою, а також здійснити винагороду за побої згідно зі становим становищем того, кого побили [5, с. 211-212].

Окремі дослідники відзначають, що кримінальне процесуальне право України XIV-XVII ст. відрізнялося поєднанням литовського, польського, російського та українського кримінального процесуального законодавства [6, с. 181]. Можна певною мірою погодитися 3 поглядом Г.К. Кожевнікова, згідно з яким, зважаючи на те, що більша частина сучасної України входила до складу Російської імперії, доцільно розглянути становлення i правове забезпечення діяльності органів досудового розслідування саме на ії території [7, с. 291]. Але паралельно ми будемо торкатися окремих норм права, виданих іншими державами, до складу яких входили окремі території сучасної України.

У цілому питання арешту майна тісно пов'язано з поняттями обшуку, виїмки, огляду, випливає з них. Розвиток інституту накладення арешту на майно нерозривно пов'язаний з інститутами обшуку, виїмки, огляду, розвивався саме з необхідності впорядкування вирішення частки вилучених об'єктів після проведення обшуку, виїмки, огляду, з необхідності відшкодування завданої шкоди, притягнення до кримінальної відповідальності. Окремі питання розвитку обшуку, виїмки, огляду будуть розглянуті у статті.

Уже у XVII ст. в наявності норми, за якими здійснюється вилучення викраденого майна. Так, у ст. 52 глави XXI Соборного уложення Російської держави 1649 р., до складу якої входила певна частина сучасної України, вказано, що «а будет кто купить лошадь ... или в городах и в уездах: и те лошади купцом записувати в таможенные книги в шерсть, и в лета и в приметы, а кто купя лошадь, в книги не запишет, а сыщется про то до пряма: и по нем за то взяти протаможье, по Государеву указу. А кто будеть у него за такую незаписанную лошадь поимаемается и взыщет с тою лошадью чего иного: и у него ту лошадь взяв, отдати истцу, а в достальном иску на него дати суд, и с суда учинити указ, до него доведеться» [8, c. 144].
У ст. 87 глави XXI Соборного уложення Російської держави 1649 р. викладені положення щодо проведення обшуку з метою встановлення викраденого майна: «А будет кто у кого в дому сведает поличное, и похочет то поличное выняти, и ему на то поличное взяти и с приказу пристава, а приставу взяти с собою понятых, сторонних людей, добрых, кому мочно верити, и поличное выняти с теми людьми, куды он послан будет искати, и то поличное выняв, отвести в приказ с теми же людьми, при ком то поличное вымет. А будет в том дому, где то поличное будет никого не застанут, и то поличное по тому же отнести в приказ с понятыми, а в приказе про то поличное сыскивати и росправа чинити по указу, до чего доведется, а бес понятых приставу поличного не выимати. А будет кто в дому своем поличного искати и клети и иных хором отомкнути не даст, или поличное и татя у пристава, и у понятых отоймет, а сыщется про то допряма, и на том, кто так учинит, истцу доправити убытки, по сыску, все сполна» [9, с. 283-284]. При цьому про заходи, спрямовані на арешт майна, у Соборному уложенні не йдеться, але йдеться про певні засоби процесуального забезпечення щодо встановлення викраденого майна та його безперешкодного вилучення.

В.В. Горошко, досліджуючи проблему тимчасового вилучення майна, дійшла висновків, що до кінця XVIII ст. слідчий процес як самостійний вид державної діяльності склався і включав у себе два види (попередній і формальний) та проводився поліцією. Історичні тенденції в розвитку правових основ виїмки сформували сучасний рівень правового регулювання даної слідчої дії і її правових наслідків: арешт майна і грошових коштів, зберігання, передача або знищення речових доказів, конфіскація майна за вироком суду або повернення законному власнику [10, с. 53].

М.П. Водько зазначає, що у Російський імперії після судової реформи 1864 р. відбулася відміна інквізиційного процесу [11, с. 125]. На думку В.Б. Іскандірова, судова реформа 1864 р. мала велике значення для судового провадження в Російський імперії. Реформа являє собою початок нової епохи у судочинстві, її результати стосуються і проведення такої процесуальної дії, як накладання арешту на майно [12, с. 35].

Так, у ст. 268 Статуту кримінального судочинства від 20 листопада 1864 р. передбачалося, що коли за обставинами справи судовий слідчий упевниться в необхідності прийняти невідкладні заходи до забезпечення можливого 


\section{Актуальні проблеми \\ історико-правової науки}

грошового стягнення на обвинуваченого або позову про винагороду за шкоду і збитки, заподіяні його діями, то про накладення заборони або арешту на майно обвинуваченого входить із поданням до окружного суду. Згідно зі ст. 305 вказаного Статуту, особа, що принесла скаргу, може просити про вжиття заходів до забезпечення відшукуваного ним майна. Але судовий слідчий входить до суду з поданням про прийняття таких заходів лише в тому разі, коли визнає прохання позивача ґрунтовним [13].

Способи та порядок накладення заборони чи арешту на маєток обвинуваченого були встановлені у ст. ст. 602-626 Статуту цивільного судочинства 1892 р. До кінця XIX ст. вказана процесуальна дія була остаточно сформована, регламентована у кримінальному та цивільно-процесуальному законодавстві, призначалася тільки для забезпечення відшкодування майнових стягнень [12, с. 35].

Після Жовтневого перевороту 1917 р. у зв'язку 3 переоцінкою відношення до права власності у радянській державі спостерігається відсутність уваги до забезпечення майнових прав громадян. Підтвердженням цьому служить те, що інститут накладення арешту на майно детально не регламентувався. У ці роки кримінально-процесуальні норми, як і норми інших галузей права, розрізнено містилися в надзвичайного характеру декретах, які приймалися Всеросійським Центральним Виконавчим Комітетом і Радою Народних Комісарів. Декретами радянської влади того часу накладення арешту на майно забезпечувалися реквізиція і конфіскація майна [12, с. 35-36].

Так, постановою Народних Комісарів по внутрішніх справах і юстиції у 1918 р. було затверджено Інструкцію «Про організацію радянської Робоче-Селянської міліції». Пунктами 27, 28 розділу Інструкції на міліцію покладалися обов'язки дізнання по кримінальних злочинах і проступках, провадження у порядку, передбаченому особливим циркуляром, обшуків, оглядів, виїмок як по документах, складених народними судами і слідчими комісіями, так і в особливих випадках за власною ініціативою для недопущення укриття слідів злочину [14, с. 15].

Відповідно до декрету від 16 квітня 1920 р. Ради Народних Комісарів «Про реквізиції і конфіскації», конфіскацією вважається безоплатне примусове відчуження державою майна, що знаходиться у володінні приватних осіб і товариств. Право конфіскації належить органам влади, а також Президії Всеросійської Надзвичайної
Комісії, Революційним Трибуналам і Народним Судам, які застосовують цей захід як покарання. Революційні Трибунали і Народні Суди свої постанови про конфіскацію вносять у судові вироки. Під час кожної реквізиції, конфіскації й арешті майна складається в момент відібрання особливий акт із точним зазначенням: 1) формальних підстав, за якими вони проводяться; 2) реквізованого, конфіскованого або арештованого майна. Власнику реквізованого або конфіскованого майна видається не пізніше трьох днів копія вищезазначеного акту [15].

При цьому після Жовтневого перевороту 1917 р. певний час діяло кримінально-процесуальне законодавство до прийняття нового. Так, згідно зі ст. 8. Декрету від 07 березня 2018 р. № 2 «Про суд», судочинство як у цивільних, так і у кримінальних справах відбувалося за правилами судових статутів 1864 р. остільки, оскільки вони не відмінені декретами Центрального Виконавчого Комітету Робочих, Солдатських, Селянських i Козацьких Депутатів і Ради Народних Комісарів і не суперечать правосвідомості трудящих класів [16].

У 1920-1921 рр. була створена й активно функціонувала комісія Народного комісаріату юстиції з підготовки проєкту КПК УРСР, яка на перших порах іменувалася «ннструкцією кримінального судочинства». П.Т. Землянский зазначає, що представники Української РСР прийняли безпосередню участь у роботі над проєктом КПК РРФСР, який, по суті, $\epsilon$ результатом роботи всіх республік під керівництвом представників Народного комісаріату юстиції Російської Федерації [17, с. 21-22].

13 вересня 1922 р. було затверджено КПК УРСР, який закріплював принципи судочинства та інші питання. Зокрема, Кодекс регламентував порядок проведення обшуків, виїмок [3, с. 337-338].

Після прийняття 31 жовтня 1924 р. Основ кримінального судочинства СРСР і союзних республік, а 23 жовтня 1927 р. - «Положення про судоустрій УСРР» 27 липня 1927 р. було затверджено новий КПК. Зміст його відображав тенденцію посилення силового тиску держави на суспільство [3, с. 338].

Цікавим $\epsilon$ арт. 118 указаного КПК, відповідно до якого слідчий має право за клопотанням потерпілого або із власної ініціативи вжити заходів до забезпечення позову, коли визнає, що невжиття цих заходів може позбавити потерпілого можливості відшкодування. Частина 2 вказаного арт. передбачає, що слідчий, побачивши, що потерпілому спричинено матеріальну шкоду і що $є$ підстава сподіватися подання позову, має право вжити заходів щодо забезпечення позову, 
хоча його ще не подано. Згідно з арт. 119 КПК, у разі притягнення до відповідальності особи за вчинення злочину, за який санкція Кримінального кодексу передбачає конфіскацію майна, слідчий, щоб забезпечити виконання вироку, має право зі своєї ініціативи, а на пропозицію прокурора вжити заходів, щоб запобігти приховуванню майна [18].

25 грудня 1958 р. були прийняті Основи кримінального судочинства Союзу РСР та союзних республік, у ст. 25 «Цивільний позивач» указаних Основ було вказано про накладення арешту на майно таким чином; «цивільний позивач» чи його представник мають право прохати орган дізнання, слідчого і суд про прийняття заходів забезпечення заявленого ними позову [19].

Відповідно до вказаних Основ, у прийнятих кримінально-процесуальних кодексах республік СРСР регламентація арешту майна отримала детальний характер. 28 грудня 1960 р. було прийнято КПК УРСР, який набув чинності 01 квітня 1961 р. Відповідно до ст. 125 указаного КПК, слідчий за клопотанням цивільного позивача або зі своєї ініціативи зобов'язаний ужити заходів щодо забезпечення заявленого в кримінальній справі цивільного позову, а також можливого в майбутньому цивільного позову, склавши про це постанову. У справах про злочини, за які кримінальним законом передбачена конфіскація майна, слідчий був зобов'язаний ужити необхідних заходів щодо забезпечення виконання вироку в частині можливої конфіскації майна, склавши про це постанову.

СТ. 126 указаного КПК передбачала забезпечення цивільного позову і можливої конфіскації майна шляхом накладення арешту на вклади, цінності та інше майно обвинуваченого чи підозрюваного або осіб, які несуть за законом матеріальну відповідальність за його дії, де б ці вклади, цінності та інше майно не знаходилися, а також шляхом вилучення майна, на яке накладено арешт [20].

Необхідно зазначити, що у статтях відносно детально розписано порядок накладення арешту на майно, його описування, передачу на зберігання. При цьому окремі положення ст. ст. 125-126 КПК 1960 рр. потребують ретельного розгляду в частині можливого запровадження в чинній редакції КПК України.

Прийняття нового КПК у 2012 р. [21] за часів набуття незалежності Україною стало відправною точкою у реформуванні кримінального процесуального законодавства України. Новелами КПК $\epsilon$ впровадження принципу процесуальної змагальності та рівності у збиранні й наданні доказів, забезпечення додаткових гарантій учасникам судочинства, особливо під час вибору запобіжних заходів, надання правової допомоги та ін. У новому КПК окремою главою 17 «Арешт майна» у ст. ст. 170-175 передбачено арешт майна як один із заходів забезпечення кримінального провадження. На відміну від усіх попередніх КПК Кодекс 2012 р. найбільш детально регламентував інститут арешту майна.

Зауважимо, що під час вирішення питання періодизації історичного розвитку інституту арешту майна у кримінальному процесі необхідно брати за основу періодизації перехід на якісно новий, відмінний від попереднього рівень розвитку явища. Ураховуючи погляд А.А. Десятника на історичну періодизацію розвитку інституту виявлення причин правопорушення та умов, які сприяли його вчиненню [22, с. 13], історію формування інституту арешту майна у кримінальному процесі на території України, умовно можна поділити на п'ять історичних етапів: 1) до судової реформи 1864 р. в Російській імперії; 2) від судової реформи 1864 р. до Жовтневого перевороту 1917 р.; 3) від Жовтневого перевороту 1917 р. до прийняття у 1958 р. Основ кримінального судочинства Союзу РСР та союзних республік; 4) від прийняття у 1958 р. Основ кримінального судочинства Союзу РСР та союзних республік та на період дії КПК України 1960 р.; 5) від набрання чинності КПК України 2012 р. дотепер.

Висновки. Подальший розвиток кримінального процесуального законодавства, у тому числі інституту арешту майна у кримінальному процесі, неможливий без знання історії виникнення певної юридичної проблематики для врахування недоліків та окремих позитивних елементів.

Сучасний стан інституту арешту майна у кримінальному процесі склався в процесі формування в різні етапи становлення Української держави від часів Київської Русі до набуття Україною незалежності. Прийняття нового КПК у 2012 р. стало відправною точкою у реформуванні кримінального процесуального законодавства України.

Історію формування інституту арешту майна у кримінальному процесі на території України умовно поділено на п'ять історичних етапів: 1) до судової реформи 1864 р. в Російській імперії; 2) від судової реформи 1864 р. до Жовтневого перевороту 1917 р.; 3) від Жовтневого перевороту 1917 р. до прийняття у 1958 р. Основ кримінального судочинства Союзу РСР та союзних республік; 4) від прийняття у 1958 р. Основ кримінального судочинства Союзу РСР та союзних республік та на період дії КПК України 1960 р.; 5) від набрання чинності КПК України 2012 р. дотепер. 


\section{Література}

1. Лекарь А.Г., Лукашов В.А. Основоположники теории оперативно-розыскной деятельности. URL: http://zvezda-r.ru/vspomogatelnoe-2012/3190ord2019.

2. Руська правда. Тексти на основі 7 списків та 5 редакцій / склав та підготував до друку проф. С. Юшков. Київ : Українська академія наук, 1935. URL: http://litopys.org.ua/yushkov/yu.htm (дата звернення: 20.02.2021).

3. Історія держави і права України : підручник / А.С. Чайковський (кер. авт. кол.) та ін. ; за ред А.С. Чайковського. Київ : Юрінком Інтер, 2004. 512 с.

4. Статути великого князівства Литовського : у 3-х т. Т. 2 Статут Великого князівства Литовського 1566 року. Анотація / за ред. С. Ківалова, П. Музиченка, А. Панькова. Одеса : Юридична література, 2003. 560 c. URL: http://biblioteka.cdu.edu.ua/cgibin /catsearch.pl?qtype $=$ simpleqquery $=\% \mathrm{D} 0 \% \mathrm{BB} \% \mathrm{D0} \% \mathrm{~B} 8$ \%D1\%82\%D0\%BE\%D0\%B2\%D1\%81\%D1\%8C\%D0\%BA\%D0\%B8 $\% \mathrm{D} 0 \% \mathrm{~B} 9$.

5. Статут Великого княжества Литовского 1529 года. Минск : Академия наук БССР, 1960. 253 c. URL: https://study.shmat.by/statut-vklvelikogo-knyazhestva-litovskogo-1529/.

6. Нагорняк-Данилюк 0.0. Історія та розвиток інституту спеціального кримінального провадження в Україні. Південноукраїнський правничий часопис. 2015. № 3. C. 181-185.

7. Кожевніков Г.К. Реформа досудового слідства закінчилась? Вісник Харківського начіонального університету імені В.Н. Каразіна. Серія «Право». 2013. № 16. C. 291-294.

8. Полное собрание законов Российской империи. Т. І. Санкт-Петербург : Тип. ІІ. Отд. Собств. Е.И.В. Канц., 1830. 1380 с.

9. Тихомиров М.Н., Епифанов П.П. Соборное уложение 1649 года. Москва : Моск. ун-т, 1961. 444 с. URL: http://www.hist.msu.ru/ER/Etext/1649/21.htm.

10. Горошко В.В. Тимчасове вилучення майна (кримінальний процесуальний аспект) : дис. ... канд. юрид. наук : 12.00.09 «Кримінальний процес та криміналістика; судова експертиза; оперативно-розшукова діяльність». Одеса, 2018. 245 с.

11. Водько Н. Об основных понятиях теории предотвращения преступных деяний. Юридичний вісник. 2013. № 1. С. 125-129.

12. Искандиров В.Б. Исторический аспект развития и становления наложения ареста на имущество как меры принуждения в России. Вестник ЮурГУ. 2010. № 38. C. 35-39. URL: https://cyberleninka.ru/ article/n/istoricheskiy-aspekt-razvitiya-i-stanovleniyanalozheniya-aresta-na-imuschestvo-kak-meryprinuzhdeniya-v-rossii.

13. Устав уголовного судопроизводства. URL: https: / / constitution.garant.ru/history/act16001918/3137/.

14. Сборник законодательных документов по вопросам организации и деятельности советской милиции, Москва : Высшая школа МВД СССР, 1957. 279 c.

15. Декрет від 16 квітня 1920 року Ради Народних Комісарів «Про реквізиції і конфіскації». URL: http://www.libussr.ru/doc_ussr/ussr_594.htm.

16. Декрет від 07 березня 2018 року № 2 «Про суд». URL: http://www.libussr.ru/doc_ussr/ ussr_254.htm.

17. Землянский П.Т. Развитие уголовно-процесуального права УССР в первые годы советской власти (1917-1922) в свете ленинских идей о кодификации : автореф. дис. ... канд. юрид. наук. Київ, 2017. 24 с. URL: http://dspace.nlu.edu.ua/ bitstream/123456789/15551/1/Zemliyanskiy_1970. pdf.

18. Кримінально-процесуальний кодекс УСРР. Харків : Юридичне видавництво Наркомюсту УСРР, 1928. $126 \mathrm{c}$.

19. Об утверждении основ уголовного судопроизводства Союза СССР и союзных республик : Закон CCCP от 25.12.1958. URL: http://www.libussr.ru/doc_ ussr/usr_5359.htm.

20. Кримінально-процесуальний кодекс України : Закон України від 28. 12. 1960 р. № 1001-05 / Верховна Рада УPCP. URL: https://zakon.rada.gov.ua/laws/ show/1001-05\#Text.

21. Кримінальний процесуальний кодекс України : Закон України від 13 квітня 2012 р. № 4651-VI / Верховна Рада України. URL: https://zakon.rada.gov.ua/ laws/show/4651-17\#Text.

22. Десятник А.А. Теоретико-правові засади виявлення причин правопорушення та умов, які сприяли його вчиненню, у кримінальному провадженні : автореф. дис. ... канд. юрид. наук. Ірпінь, 2015. 19 с.

Баженова А. І., аспірант кафедри кримінального процесу одеського державного університету внутрішніх справ 